The transversal statistical study, involving 38 infants, distributed into three groups, showed a significant difference, using the Kruskal-Wallis test for the standing position, between the group of preterm infants with gestacional age between 32 and 36 weeks and the group of at term infants, in the $4^{\text {th }}$ and $5^{\text {th }}$ month of age. The longitudinal statistical study, considering 24 infants that never missed na evaluation and the preterm infants grouped showed significant difference, using the Analysis of Variance, in the following situations: prone position with the group of preterm infants, between evaluations carried out at 15 days and $1^{\text {st }}$ month, $2^{\text {nd }}$ and $3^{\text {rd }}$ month, $3^{\text {rd }}$ and $4^{\text {th }}$ month, $4^{\text {th }}$ and $5^{\text {th }}$ month and $5^{\text {th }}$ and $6^{\text {th }}$ month, and group of at term infants, in the evaluations carried out between 15 days and the $1^{\text {st }}$ month, the $1^{\text {st }}$ and $2^{\text {nd }}$ month, the $2^{\text {nd }}$ and $3^{\text {rd }}$ month, the $3^{\text {rd }}$ and $4^{\text {th }}$ month, $4^{\text {th }}$ and the $5^{\text {th }}$ month and $5^{\text {th }}$ and $6^{\text {th }}$ month; sitting position, indi- cating that the preterm group showed, in average, inferior results to those for the at term group; standing position, between the two groups at the $4^{\text {th }}$ and $5^{\text {th }}$ month, and within the group of preterm infants, in the evaluations carried out between the $3^{\text {rd }}$ and $4^{\text {th }}$ month and the $5^{\text {th }}$ and $6^{\text {th }}$ month and the at term group in the evaluations between the $3^{\text {rd }}$ and $4^{\text {th }}$ month.

Results from this study demonstrate that early postural control during the first six months of age developed sequentially in preterm and at term infants, however, slower in the former. The Chailey Levels of Ability assessment showed that there was a relationship between the lying (supine and prone) and the sitting positions, and between the sitting and the standing positions.

KEY WORDS: early postural control, preterm infants, Chailey levels of ability.

*Controle postural precoce em crianças nascidas pré-termo e a termo (Resumo). Tese de Doutorado, Universidade Estadual de Campinas, UNICAMP (Área: Ciências Biomédicas). Orientadora: Maria Valeriana Leme de Moura-Ribeiro.

**Address: Departamento de Fisioterapia UEL, Avenida Robert Koch 60 -86038-350 Londrina PR - Brasil. E-mail: gaetan@sercomtel.com.br

\title{
EXPRESSION OF THE CHEMOKINES CXCL10 AND CCL2 IN SERUM AND CEREBROSPINAL FLUID OF PATIENTS WITH MULTIPLE SCLEROSIS TREATED WITH INTRAVENOUS METHYLPREDNISOLONE (ABSTRACT)*. DISSERTATION. SÃO PAULO, 2004.
}

\author{
MARCOS MOREIRA**
}

Studies of chemokines in cerebrospinal fluid (CSF) of patients with active multiple sclerosis have indicated that specific chemokines may develop an important role in the pathogenesis of the disease. Chemokines and its receptors have been associated with the migration of lymphocytes, monocytes, eosinophils, basophils and neutrophils under physiological and pathological conditions and have been considered important targets for investigation.

We have investigated the expression of two biologically important chemokines (CCL2 and CXCL10) in CSF and serum of 14 patients with relapsing multiple sclerosis (MS) and 14 controls with noninflammatory CSF and 14 healthy individual's serum controls. We have also investigated the expression of these chemokines and the clinical alterations measured through Expanded Disability Status Scale (EDSS), Neurologic Rating Scale (NRS) and Ambula- tory Index (AI) for MS before and after the treatment with intravenous methylprednisolone (IVMP) for five days.

In the admission, CCL2 concentrations were lower in MS patients than in controls; however, CXCL10 concentrations have demonstrated being higher in MS patients than in controls. The treatment has significantly changed the CCL2 and CXCL10 levels in CSF before and after the treatment. There was a statistically significant scores improvement of all the scales applied (EDSS, NRS and AI) soon after the end of the treatment.

Our results indicate that higher CXCL10 concentrations in the CSF and lower CCL2 concentrations are associated with relapses in multiple sclerosis.

KEY WORDS: multiple sclerosis, glucocorticoids, cerebrospinal fluid, chemokines, CXCL10; CCL2; methylprednisolone

\footnotetext{
* Expressão das quimiocinas CCL2 e CXCL10 no soro e líquido cefalorraquiano de pacientes com esclerose múltipla tratados com metilprednisolona intravenosa (Resumo). Dissertação de Mestrado, Faculdade de Ciências Médicas da Santa Casa de São Paulo (Área: Clínica Médica). Orientador: Charles Peter Tilbery.

** Address: Rua Cardoso de Almeida 634 / 93, 05013-000 São Paulo SP, Brasil. E-mail: drmarcosmoreira@uol.com.br
} 